\title{
Tipologi Pemikiran Cendikiawan Muslim
}

\author{
Ridwan \& Abdul Wahab Rosyidi
}

Penulis adalah Dosen Fak. Humaniora dan Budaya Universitas Islam Negeri (UIN) Malang

\begin{abstract}
In the process of the development of intellectualisme, the role of Moslem scholars who were successful to make a dynamic athmosphere in Islamic thaughs to point out. Their popular and well-socialized thoughts develop and bring positif on the knowledge and the perseption of religion in the society. The development of the scholar's Islamic thought has different characteristic and pattern which is interesting to analyze. The purpose of analysis is to enlarge our knowledge on the Islamic thought, especially those which were written in daily newspaper "Jawa Pos" during the Romadhon I425 H. To sum up, essay which were written by same Moslem scholars has different characteristic: first, the understandings about "Fasting" are vasied. The scholar's have different perception on it. Second the different point of view create different way of thingking. Those are: Formalistic, Transformatic, Realistic, and Idealistic which all lead to the socio cultural cheng.
\end{abstract}

\section{A. Pendahuluan}

Mengamati perkembangan studi Agama di Indonesia sangat menarik, terutama lima ahun terakhir ini. Berbagai jurnal, banyak di antaranya dari semula memang bukan diterbitkan secara khusus untuk studi Agama ikut memuat dan mengangkat isu-isu keAgamaan. Jika diamati secara seksama, baik dengan atau tampa melihat kualitas tulisan yang termuat dalam berbagai penerbitan kumpulan

Ulal Albab, Vol. 5 No. 2, 2004 
makalah maupun yang termuat dalam berbagai jurnal, hampir dapat disimpulkan bahwa tulisan-tulisan tersebut muncul dari anggota masyarakat yang tidak sepenuhnya terlibat dalam berbagai aktivitas organisasi kelembagaan Agama yang ada. Ada satu atau dua pengecualian, sudah barang tentu, namun pada umumnya, para penyumbang tulisan tersebut muncul dari kalangan peneliti dan pemerhati masalah-masalah sosial dan keAgamaan.

Studi Ilmiah Agama (religionswissenschaft) di era postmodernisme, seperti penuturan Amin Abdullah, meskipun semakin diperlukan orang bukan berarti bisa dilakukan dengan mudah oleh setiap orang. Untuk melakukannya diperlukan latihan akademik-ilmiah (academic-scientifid training) dalam jangka waktu singkat.'

Peranan Agama dalam masyarakat amat ditentukan oleh pandangan masyarakat itu tentang Agama. Pandangan inilah yang akan menentukan peranan Agama di dalam masyarakat. Kajian ilmiah mengenai Islam di Indonesia menyangkut berbagai permasalahan yang tidak semuanya transparan bagi banyak orang, sehingga hasilnya juga tidak bisa dianggap selalu benar. Mengenali dan memahami sebaik mungkin permasalahan merupakan langkah dan strategi yang penting untuk bisa menentukan pilihan jenis kajian ilmiah Islam yang lebih tepat atau lebih urgen.

Kenyataannya, di kalangan kaum muslimin masih terdapat perbedaan visi dalam memahami Islam itu sendiri. Padahal, perbedaan ini sangat menentukan pandangan seseorang terhadap kajiannya. Sebagian dari mereka memahami Islam itu sebatas ritual seremonial dan sebagian yang lain memahaminya secara universal, menyangkut semua dimensi kehidupan. Belakangan populer dikalangan muslimin tertentu (menurut istilah Yusuf al-Qardawi orang yang sangat bersemangat seputar masalah yang dilontarkan budak-budak pemikiran Barat) dengan pembagian Islam menjadi Islam Politik, Islam Kultural dan lain sebagainya. Menurut Yusuf al-Qardhawi cara pembagian seperti itu harus ditolak karena merupakan pelaksanaan program yang dirancang musuh-musuh Islam untuk memecah-mecah dan membagi-bagi Islam yang utuh, sebagaimana yang diturunkan Allah dan sebagaimana Agama yang dianut kaum muslimin. la hanyalah Islam parsial yang beraneka ragam dan berbeda-beda sebagaimana yang mereka sukai $^{2}$ 
Pada tahun 80-an terjadi iklim dan suasana kondusif bagi perkembangan pemikiran keIslaman di Indonesia, hal ini terjadi karena makin terbukanya kesempatan untuk memperoleh jenjang pendidikan yang lebih tinggi baik di dalam maupun luar negeri. Meningkatnya jumlah penerbitan dan lektur keAgamaan, tersedianya berbagai sarana untuk mengartikulasikan kegiatan keilmuan dan sebagainya, telah mendorong terjadinya proses intelektualisasi yang massif di kalangan kaum santri. ${ }^{3}$

Dalam proses kebangkitan intelektualisme itu, sangat penting untuk dicatat peranan sejumlah cendekiawan Muslim yang berhasil menyemarakkan dinamika intelektual di Indonesia. Pemikiran-pemikiran mereka yang populer dan tersosialisasikan dengan baik di masyarakat, berdapak luas bagi pengembangan wawasan berfikir dan persepsi keAgamaan mereka.

Namun demikian perlu dicatat, perkembangan pemikiran keIslaman para cendekiawan itu memiliki karakter dan tipologi berbeda, yang sangat menarik sekali untuk kita kaji dan teliti lebih jauh tentang tema-tema dan wacana kajian mereka dalam rangka meningkatkan wawasan kita terhadap pemikiran cendekiawan Muslim, utamanya tema-tema yang disampaikan lewat media masa baik tulis atau elektronik

Jawa Pos salah satu harian pagi yang memuat kajian-kajian keIslaman utamanya dibulan suci Ramadlan, dan kajian keIslaman yang ada banyak ditulis oleh orang-orang yang kompeten di bidangnya, baik taraf nasional maupun internasional. Kajian ini merupakan awal bijakan seorang peneliti untuk mengetahui tipologi dan tema wacana kelslaman dari cendekiawan muslim.

Berdasarkan pemikiran tersebut di atas, maka perlu dilakukan penelitian tentang tipologi pemikiran kelslaman cendekiawan Muslim di Harian Pagi Jawa Pos selama bulan Ramadlan $1425 \mathrm{H}$. Dengan menempatkan tulisan-tulisan kelslaman pada rubrik "Esai Ramadan" dengan harapan agar dapat dikaji dengan seksama tentang tipologi kajian kelslaman cendekiawan yang semakin komplek.

\section{B. Metode dan Prosedur Penelitian}

Penelitian ini menggunakan pendekatan diskriftif Kualitatif, sebab datanya dalam bentuk simbolik, seperti pernyataan, tafsiran, tanggapan, non verbal dan 
grafik. ${ }^{4}$.sedangkan metode yang digunakan adalah: Deduktif, yang berangkat dari pengetahuan yang sifatnya umum, metode ini digunakan untuk menguraikan suatu pendapat atau pengetahuan yang bersifat lebih terinci, sehingga akan memperjelas pembahasan dan mempermudah pemaknaan. Sedangkan untuk mengambil kesimpulan digunakanlah metode Induktif

Data-data yang dibutuhkan berupa literatur, dokumen dan data empirik atau lapangan. ${ }^{5}$ Adapun data yang digunakan dalam penelitian ini adalah tulisan yang dimuat oleh Koran Jawa Pos pada rubrik Esai Ramadan mulai yanggal 1 Ramadlan s/d 30 Ramadan $1425 \mathrm{H}$. sedangkan teknik pengumpulan data dengan cara mengumpulkan tulisan-tulisan/makalah selama bulan Ramadlan $1425 \mathrm{H} /$ 2004 M. di koran jawa Pos, kemudian dianalisa lewat Content Analysis.

\section{Pembahasan}

Analisis Terhadap Tipologi Pemikiran Cendekiawan Muslim Pada Rubik Esai Romadhon

Yang dimaksud dengan tiplogi pemikiran cendekiawan Muslim di sini adalah suatu kajian tentang tipe-tipe pemikiran keIslaman dari para cendekiawan Muslim Indonesia. Pemikiran kelslaman merupakan analisis, respon, dan refleksi mereka terhadap peristiwa dan permasalahan keIslaman di Indonesia. M. Syafi'i Anwar mencatat ada beberapa tipologi pemikiran yang dikembangkan di Indonesia : Formalistik, Transformatik, Realitik, Idialistik, Subtantivistik, Totalistik.

\section{Formalistik}

Karakteristik utama tipe pemikiran formalistik adalah ditunjukkan oleh adanya model pemikiran yang mengutamakan peneguhan dan ketaatan yang ketat pada format-format ajaran Islam. Dalam konteks sosial, tipe pemikiran seperti ini cenderung mengabaikan dimensi sosial kemanusiaan-kemasyarakatan. Sebuah gagasan atau pemikiran dipahami dan difokuskan pada penalaran-penalaran formal-tekstual, tanpa mempertimbangkan konteks luar sehingga sisi eksternal teks (realitas kehidupan di luarnya) tidak disentuh atau bahkan dengan sengaja 
diabaikan. Model pemikiran seperti ini hanya lebih meneguhkan kesalehan pribadi ketimbang kesalehan sosial.

Sebagaimana sudah maklum, bahwa sebuah teks (baca: ajaran) tidak lahir dari dunia yang hampa. Ia terkait erat dengan konteks yang berada di luar dirinaya. Oleh karena itu, sebuah teks (ajaran) pasti memiliki proyeksi ke depan mengenai realitas dunia. Proyeksi mengenai realitas dunia itulah yang menjadikan sebuah teks atau ajaran mempunyai tujuan. Dan tujuan ini tidak lain kembali kepada manusia. Ya, itulah yang dalam bahasa ushul fiqh disebut dengan al-Mashlahah.

Setidaknya, tipe pemikiran formalistik tersebut juga dapat dibaca dalam beberapa tulisan cendekiawan muslim. Syamsuddin M. dalam memaknai tentang "Ramadhan dan Puasa" lebih menekankan pada tradisi keAgamaan yang dianggap telah mapan dalam Islam. Ia menganggap bahwa Ramadhan dan puasa itu identik dengan iktikaf, menanti malam lailatul qadar, berdzikir tengah malam, mengaji al-Qur'an. Beberapa ritual ibadah tersebut perlu diteguhkan dan ditanamkan kepada anak anak (muslim), bahkan kepada semua umat Islam.

Meskipun modernitas yang ditandai oleh kecanggihan teknologi menjadikan perasaan kita miris atau khawatir, namun kenyataan itu tetap tidak bisa ditolak. Penolakan terhadapnya bahkan bisa menjadi bumerang buat dirinya. Ketika pada zaman dahulu anak-anak bermain kuda-kuda dengan pelepah pisang, membuat mainan motor dari kulit jeruk Bali, atau bahkan menghabiskan waktunya untuk bermain gobag sodor dan berbagai jenis permainan tradisional yang lain, maka sekarang semua itu digantikan dengan permainan yang serba otomatis. Ada Play Station, mainan mobil yang pakai remote controle dan lain sebagainya. Kini, semua telah berubah serba otomatis, digital dengan desain teknologi yang sedemikian rupa sehingga menarik untuk dapat dijadikan hiburan, baik anak-anak maupun orang dewasa.

Menurut Syamsuddin M, kecanggihan teknologi seperti itu seharusnya tidak menggusur ritual khas dalam bulan Ramadhan. Banyak cara yang dapat dilakukaan untuk membiasakan ritualitas tersebut kepada anak khususnya, dan umat Islam pada umumnya. Cara-cara itu dapat disintesakan, seperti bagi mereka yang hobi main game wajib membaca basmalah dalam setiap memulai permainan. Kalau memang harus mengucapkan hamdalah, dan kalau kalah menyebut subhanallah. Membudayakan dalam permaianan anak-anak di bulan ramadhan (sepuluh hari terakhir) dengan kata iktikaf. Maka, ajakan main ajakan main play station dibubuhi

Ulual Albab, Vol. 5 No. 2, 2004 
kata iktikaf sehingga menjadi iktikaf main play station. Atau kata iktikaf main internet dan lain sebagainya. ${ }^{6}$ Mentradisikan ritualitas keAgamaan seperti di atas tidak akan memiliki arti apa-apa, kecuali peneguhan ritual-ritual yang diidentikkan dengan Ramadhan dan puasa. Yang terpenting bukanlah membiasakan kosa kata keAgamaan untuk dijadikan istilah-istilah baru menggantikan istilah lama: main play station menjadi iktikaf main play station. Permainan tetap permainan. Maka semestinya yang terpenting adalah bagaimana merubah perilaku anak atau umat Islam yang hobi menghabiskan waktunya untuk duduk di depan play station menjadi perilaku-perilaku yang lebih bermanfaat bagi diri dan Agamanya? Maka, "bagaimana bulan Ramadhan dan puasa itu bisa dijadikan sebagai sarana untuk melakukan revolusi perilaku, menuju kebiasan yang lebih produktif-progresif?"' menjadi pertanyaan yang mendasar dan penting dalam konteks keterkaitan puasa dengan realitas sosial.

Model pemikiran formalistik juga dapat dilihat dalam tulisan Nurhadiani. Ia memaknai Ramadhan dan puasa juga tidak beranjak dari cara berpikir Syamsuddin, lebih menekan aspek formalisme ajaran Agama. Menurut Nurhadiani, puasa hendaknya jangan dinodai oleh perasaan su'udzan, ngegasip, berbohong, mengadu domba (namimah), menonjolkan syahwat dan perilaku negatif lainnya. Statemen ini ia nyatakan dalam keterkaitannya dengan realitas orang pasaran.?

Sudah maklum, bahwa Nabi Saw pernah menegaskan bahwa "pasar merupakan tempatnya setan". Agaknya, Nurhadiani tidak dapat melepaskan pemaknaan puasa dari makna leteral hadits tersebut. Pasar adalah tempat bertemunya orang dari segala penjuru, tempat transaksi jual beli. Di dalamnya, sangat mungkin seseorang melakukan tindakan-tindakan negatif sebagaimana tersebut di atas. Perilaku tersebut pada kenyataannya merupakan sifat yang tidak dapat dipisahkan dari diri manusia. Dalam konteks ini, semua itu merupakan cobaan bagi manusia di dunia ini. Dalam menghadapi cobaan itu, seorang yang puasa harus bersabar. "Selalu optimis dalam menghadapi cobaan"."

Dengan demikian, menurut Nurhadiani, sabar merupakan kunci untuk mensikapi watak-watak negatif yang akan dapat mengganggu dan merusak etos manusia dalam menjalankan kebaikan. Dalam menghadapi watak-watak negatif itu, seseorang pun harus berdoa agar dijauhkan darinya. Tujuan seperti ini tidak lain diproyeksikan untuk kesuksesan puasa. Tidak lebih dari itu, yaitu meneguhkan pelaksanaan ibadah puasa an sich. 


\section{Transformatik}

Bahwa misi dasar Islam adalah kemanusiaan. Oleh karena itu, Islam harus menjadi kekuatan sebagai agent of change. Atau dengan kata lain, Islam arus menjadi kekuatan yang dapat mendorong secara terus menerus, dan mentrasformasikan masyarakat dengan berbagai aspeknya ke dalam skala-skala besar yang bersifat praksis maupun teoritis. Inilah yang menjadi ciri utama arus pemikiran transformatif.

Untuk menjelaskan corak pemikiran transformatif yang berorientasi pada terjadinya perbuahan di tingkat sosial, maka berikut dapat kita lihat gagasan Syamsul Arifin, M.A.Wicaksono, Muhaimin S, dan Baharuddin. Dalam memaknai puasa, Syamsul Arifin menyatakan bahwa Pesan esensi puasa adalah menahan dan mengendalikan nafsu. Dalam puasa terkandung upaya "kualitas" dan "efektifitas", kandungan tersebut seyogyanya dijadikan pijakan untuk mensikapi tradisi dan budaya serta ritualitas. Apapun bentuk tradisi, budaya dan ritual akan menjadi tak berarti apa-apa ketika semua itu dilihat dari sisi formalitas. ${ }^{9}$

Di tengah masyarakat Indonesia, ditemukan berbagai macam tradisi, budaya dan ritual demi menyambut ibadah puasa. Ada yang membuat kundangan (membuat apem, kue-kue atau yang sejenisnya. Ada yang mentradisikan minum jamu, memasang spanduk marhaban ya ramashan, mengadakan pondok Ramadan, acara-acara TV tiba-tiba dipenuhi kegiatan yang Islami, dan bahkan sampai menyulut mercon-meskipun yang terakhir ini lebih cenderung pada tindakan destruktif. Lebih lanjut, Syamsul melihat bahwa pesan "menahan diri dan mengendalikan nafsu" seharusnya diproyeksikan sebagai sarana untuk menyikapi berbagai budaya, tradisi dan ritualitas yang berkembang di tengah masyarakat. Apalagi budaya yang mengarah pada pelampiasan syahwat demi mengejar materi belaka (mobil Volvo menjadi symbol kehedonisan hidup) ${ }^{10}$

Jika budaya yang mengarah pada tradisi hedonistic itu terus berkembang, maka dikhawatirkan akan mengancam eksistensi kehidupan manusia: semakin memperburuk carut-marutnya tatanan masyarakat yang sudah dirundung ketidakadilan dan krisis berkepanjangan, baik krisis moral (spiritual) maupun material. Sementara itu, dalam spectrum yang agak detail, Wicaksono melihat puasa sebagai sarana untuk mengasah empat dimensi yang terdapat dalam diri manusia. Empat dimensi itu adalah fisik, mental, sosial-emosional, dan spiritual. 
Kita hidup membutuhkan semacam energi (baterai). Empat dimensi tersebut diibaratkan dengan baterai. Ketika isi energi yang terdapat dalam baterai itu habis, maka harus di-charge, sehingga menjadi prima kembali. Tujuan final puasa adalah membentuk pribadi yang takwa. Gergaji itu adalah ketakwaan yang telah menjadi terget final ibadah puasa. Puasa sebagai energi kehidupan jika dilaksanakan oleh seseorang, maka akan bertalian dengan empat dimensi yang terdapat dalam diri manusia itu sendiri. Puasa itu akan memberi energi (pengaruh) dalam keempat dimensi tersebut. Dengan demikian, puasa merupakan proses menstabilkan kembali keempat unsur dalam diri manusia dalam rangka melakukan perubahan sosial di tengah masyarakat."

Dalam semangat pemikiran yang sama (yakni transformatif), Muhaimin S. lebih membidik makna puasa dengan menggunakan teori perubahan sosial. Teori yang dimaksud mengatakan, bahwa perubahan dalam masyarakat disebabkan oleh ide, pandangan hidup, pandangan dunia dan nilai-nilai. Puasa menurutnya, merupakan olah emosi dan spiritual. Output-nya adalah peningkatan kualitas diri dalam menjalani kehidupan dan berinteraksi dengan yang lain. Dalam perspektif sosial puasa dipandang sebagai 1) alat legitimasi bahwa dirinya adalah seorang muslim. Dan ini dapat dijadikan ikon antara muslim dengan non-muslim. 2) Puasa sebagai alat penyucian diri. Maksudnya puasa hanya dijadikan sebagai proses untuk meraih kualitas individu atau kesalehan pribadi. 3) Puasa sebagai sarana perubahan. Di sini, puasa diharapkan dapat menumbuhkan tanggungjawab terhadap terciptanya masyarakat yang penuh keseimbangaan. ${ }^{12}$

Sampai sini, dapat ditarik benang simpul, bahwa puasa diharapkan memiliki dua dimensi sekaligus. Yaitu internal dan eksternal, individual dan sosial. Secara internal, puasa dapat menumbuhkan rasa penghayatan akan nilai-nilai atau makna puasa, dan secara eksternal puasa diharapkan dapat mengubah cara pandang seseorang terhadap lingkungan di sekelilingnya. Kualitas internal dan ekternal inilah yang menjadikan manusia mendapat tempat yang lebih terhormat di sisi Tuhan. Lebih jauh Muhaimin mengatakan: ${ }^{13}$ "orang berpuasa dengan sungguhsungguh mencari ridla-Nya dan berdampak pada kesalehan individu dan sosial adalah termasuk dalam kategori great individual di mata Allah, karena melalui merekalah ide, pandangan hidup, pandangan dunia dan nilai-nilai yang terkandung dalam al-Qur'an bisa dibumikan, yang pada gilirannya melahirkan peradaban baru ..." 
Namun demikian, bagi Muhaimin perubahan ide, pandangan dunia dan nilainilai tidak memiliki arti apa-apa manakala semua itu dijadikan sebagai wacana semata. Lalu, langkah apa yang dilakukan agar perubahan pandangan dunia, ide dan nilai-nilai itu tidak sia-sia? Menjawab pertanyaan itu, Muhaimin juga mengingatkan akan pentingnya gerakan praksis-sosial. ${ }^{14}$

Dalam konteks berbangsa dan bernegara, puasa mesti menjadi titik pijak untuk menata batin (niat). Puasa itu mengingatkan kita akan "janji suci" untuk siap menjalani sesuatu. Coba dibayangkan, seorang yang betul-betul puasa itu pasti mau memegang teguh niat yang telah dilafalkan sejak sebelum terbitnya fajar sampai terbenamnya matahari. Bahkan niat itu sendiri menjadi syarat sahnya puasa. Menata bangsa sebagai bagian dari tanggungjawab individu juga dapat dilakukan dengan menjadikan niat dalam puasa sebagai modelnya. Untuk itu Muhaimin menegaskan: 15 "Salah satu rukun ibadah puasa adalah "Niat" lillahi ta'ala, hadist Nabi yang berbunyi" Barang siapa yang tidak berniat akan puasa pada malamnya sebelum terbit fajar maka bukanlah ia berpuasa. Jika memperhatika kondisi bangsa yang sangat memprihatikan, rupanya niat berpuasa tidak hanya diikrarkan pada bulan romadhan saja, tetapi justru harus diucapkan dan diikrarkan secara terus menerus hingga bangsa ini terlepas dari berbagai krisis, sebab bagaimana mungkin krisis bangsa ini akan bias teratasi kalau tidak dibarengi dengan niat berpuasa. Terutama mulai dari pejabat dan konglomerat untuk diikuti oleh seluruh lapisan masyarakat. Ketua MPR yang tidak mau menerima fasilitas mobil Volvo dan menolak tidur di hotel dengan tarif 3-4 juta semalam salah satu contoh niat berpuasa yang diucapkan penguasa tertinggi negara."

Corak transformatif lain juga dapat disaksikan dalam tulisan Baharuddin. Ini nampak jelas ketika ia menafsirkan puasa sebagai kekuatan yang dapat menumbuhkan ikatan solidaritas sosial. Baginya puasa tidak saja merupakan tindakan menahan diri dari rasa haus dan lapar. Jika puasa dilaksanakan seperti itu, maka sudah dianggap sah. Tetapi justru menjadi sia-sia manakala orang yang berpuasa tidak dapat menghayati makna terdalamnya. Bukankah Rasulullah Saw pernah bersabda: "Betapa banyak orang berpuasa, namun mereka tidak mendapat apa-apa kecuali lapar dan haus dahaga."

Agaknya, isyarat yang telah diberikan nabi tersebut telah menggungah kesadaran Baharuddin. la telah keluar dari pakem pemahaman puasa yang menitikberatkan pada "lapar dan haus dahaga". Rasa lapar dan haus dahaga 
adalah makna eksoteris puasa, namun makna esoterisnya adalah:" "Diantara rahasia diwajibkannya puasa bagi umat Islam adalah dalam rangka memupuk kesetiakawanan dan solidaritas sosial kepada sesama, terutama mereka yang tidak mampu atau miskin. Dengan kata lain, kita diuji untuk merasakan kesuasahan orang lain sehingga kita terdorong untuk membantu dengan apa yang kita miliki. Dalam ibadah puasa, kita diajarkan untuk selalu menjaga keseimbangan dalam pelaksanaan ibadah mahdah dengan ibadah sosial. Jangan sampai kita rajin salat tarawih, membaca Qur'an, berdzikir, dan seterusnya, namun di sisi lain kita melupakan nasib tetangga. Hendaklah ibadah-ibadah tersebut bisa memberikan dampak atau dorongan kuat untuk bisa melakukan ibadah sosial."

\section{Realistik}

Adalah M.Zainuddin yang telah mengambil jalan realistic dalam memaknai puasa. Ciri utama tipe pemikiran realistic adalah melihat keterkaitan atau melakukan penghadapan antara dimensi substantif dari ajaran atau doktrin Agama, dengan konteks sosio-kultur masyarakat pemeluknya. Islam sebagai Agama wahyu yang universal dan bertolak dari kesempurnaan dan keabadian doktrin, perlu hadir dan menampakkan diri secara realistis dalam kerAgaman, yang diwarnai oleh perjalanan sejarah dan situasi sosial cultural umat pemeluknya.

Nilai Agama merupakan nilai yang sejalan dengan nilai tatanan sosial. Puasa sebagai salah satu bentuk ajaran dalam Islam merupakan ritual yang tidak bebas nilai keAgamaan. Keseimbangan nilai sosial di tengah masyarakat merupakan objek perhatian utama yang patut diperhatikan dalam Agama. Inilah sebenarnya dokrin Agama.

Dalam konteks doktrin seperti itu, puasa mesti memiliki makna yang luar biasa. Dimenasi sosial terpenting dari puasa adalah menundukkan ego atau nafsu yang cenderung-dalam bahasa Agama-laammaratum bis su'. Untuk mewujudkan keseimbangan tatanan kosmos dibutuhkan nafsu yang arif, sehingga tercipta ketentraman dan keseimbangan dalam kehidupan.

Kekerasan, pertengkaran, dan permusuhan merupakan perilaku yang dapat mengakibatkan kekacauaan dan keadaan serba tidak menentu. Ini jelas bertentang dengan doktrin Agama yang selalu menganjurkan pada kedamaian. Makna Islam 
adalah perdamaian. Tetapi meskipun demikian, kekerasan dan pertengkaran dalam kehidupan menjadi peristiwa yang terus mengalir dari hari ke hari. Ia seolah menjadi paradoks kehidupan.. Zainuddin mensinyalir bahwa bentuk kekerasan yang paling awal hadir ke muka bumi sejak Habil dan Qabil. Mensikapi paradoks tersebut, Zainuddin menawarkan puasa sebagai ikon yang dapat menyudahi kekerasan di muka bumi.

Dengan jelas, Zainuddin mengatakan:17 "Ada kesenjangan antara nilainilai Agama yang bersifat ajaran dan nilai sosialnya. Misalnya, orang Islam lebih peka (tersinggung) jika Agamanya dilecehkan sehingga menimbulkan permusuhan dan kekerasan diantara umat berAgama. Tetapi kurang peka dan tersinggung jika ada ketimpangan sosial dimana-mana. Ada degradasi nilai-nilai sosial, etis dan humanis. Padahal, jika dicermati ajaran Islam memiliki nilai-nilai sosial dan etika yang tinggi. Bahkan doktrin syariah ( $f i q h)$ dan akhlak dalam ajaran Islam memiliki dimensi yang sangat luas. Oleh sebab itu, persoalan ini mesti segera disadari bersama sehingga doktrin Agama menjadi semakin bermakna bagi terciptanyaa kehidupan yang seimbang dan harmonis dalam sebuah masyarakat."

Pola pemikiran yang sama juga nampak dalam tulisan Imam Suprayogo ketika memaknai puasa. Sejak awal, ia melihat bahwa bangsa Indonesia yang sangat besar ini berjalan tidak sempurna, penuh misteri, mengelikan dan sekaligus membingungkan. Bagaimana tidak, kekayaan Indonesia adalah melimah ruah tetapi kemiskinan menjadi persoalan yang sampai sekarang belum terselesaikan. Bangsa ini konon memiliki tradisi dan budaya yang luhur, tetapi kenyataannya praktek korupsi, pembunuhan, perampokan, penganiayaan, dan seambrek tindak kriminal lainnya terus silih berganti, seolah-oleh tidak akan berhenti.

Kenyataan seperti itu tentu bertentangan dengan doktrin Agama. Agama mengajarkan nilai-nilai kebaikan, kebersamaan, kemajuan, dan kemanusiaan. Kenyataan sosial yang berkembang, yang secara diametral bertentangan dengan Agama tersebut mesti harus disikapi dengan arif. Kita tidak harus mensikapinya secara paradoks. Masih ada Agama yang dapat melakukan reformasi moral dan spiritual tersebut. Dalam keterkaitan semua itu, Imam memaknai puasa sebagai kunci menuju kesuksesan hidup. Taqwa adalah tujuan final puasa. Dengan demikian, taqwa dan kesuksesan hidup tidak dapat dipisahkan. Secara jelas Imam mengatakan:" "Taqwa adalah konsep dalam Al qur' an untuk menyebut manusia sukses dalam hidup. Seorang yang mencapai derajat taqwa disebut sebagai orang

Ulul Albab, Vol. 5 No. 2, 2004 
yang memperoleh petunjuk dari Allah dan orang yang beruntung. Sehingga dalam menentukan ukuran keberhasilan dalam hidup yang disebut bertaqwa itu adalah tingkatan kualitas yang tidak saja menunjuk pada ukuran-ukuran yang bersifat material, tetapi juga sekaligus yang berdemensi immaterial yaitu berada pada kawasan batini yang disebut dengan "Iman". Sehingga ukuran keberhasilan hidup dan kualitas kemanusiaan tidak menjadi sangat sederhana sebagaimana yang didiskripsikan oleh masyarakat yang serba materialisme."

Apabila puasa itu bertujuan menciptakan pribadi yang takwa, dan ketakwaan itu merupakan kunci menuju kesuksesan dalam kehidupan, maka tentunya puasa tidak saja menjadi sesuatu yang sia-sia. Tetapi, harus dijadikan sebagai media pendidikan, atau meminjam bahasa kaum psikolog sebagai spiritual healing. Oleh karena itu, Imam lebih lanjut menjelaskan: 19 "Puasa Dalam hal ini digambarkan sebagai proses pendidikan yang berlangsung seumur hidup (minal mahdi ilal lahdi), Siapa saja yang mampu menjalankan puasa dengan sungguhsungguh, maka artinya dia sudah lulus dari ujian untuk menghindar dari perbuatan tercela dan menipu. Meninggalkan sifat buruk, semisal menipu ini, bukan pekerjaan mudah. Untuk membangun sifat itu memerlukan latihan secara terus menerus. Seseorang untuk menjadi jujur selalu merasa diawasi oleh Allah SWT, dan oleh karena itu sanggup menjaga lidahnya, tangannya, kemaluannya dari hal yang merusak puasa. Oleh karena itulah maka puasa menjadi tepat kalau disebut sebagai proses pendidikan yaitu kegiatan yang bertujuan akhir agar siapa saja yang menjalaninya lebih baik."

\section{Idialistik}

Tipe pemikiran idialistik dicirikan oleh wataknya yang bertolak dari pandangan pentingnya perjuangan umaat untuk berorientasi pada tahapaan menuju Islam yang dicita-citakan. Islam yang dicita-citakan adalah Islam sebagaimana yang tersurat dan tersirat dalam al-Qur'an dan Sunnah yang otentik. Islam citacita mengandung pandangan dunia seorang muslim yang dibentuk oleh wahyu.

Model pemikiran idialistik dapat dijumpai dalam tulisan Pudjo Sugito. Dalam al-Qur'an dinyatakan bahwa tujuan puasa adalah membentuk pribadi yang takwa 
atau muttaqin. Menjadi pribadi yang muttaqin inilah merupakan idealisasi Agama berkaitan dengan ibadah puasa. Orang yang muttaqin berarti mereka yang mampu menjaga keseimbangan ittaqa (kewaspadaan terus-menerus, bukan takut dalam pengertian sikap tertekan). Dalam makna kata ittaqa tersirat arti "mawas diri" yang dibarengi dengan usaha pro aktif, yaitu pro aktif untuk bertindak. Sehingga dengan sendirinya ada upaya perbaikan diri: kemauan untuk menghanyati apa yang dilakukan oleh diri sendiri dan mau mengoreksinya sehingga mengetahui apa-apa yang akan dapat dilakukan demi masa depannya.

Kata muttaqin juga mengisyaratkan akan jumlah yang banyak karena ia hadir dalam bentuk jamak (plural). Jumlah banyak itu tidak lain merupakan simbol akan eksistensi sebuah komunitas, masyarakat atau bahkan bangsa.

Oleh karena itu, menurut Pudjo proyeksi kata muttaqin" dimaksudkan sebagai "bangsa yang berdaya saing tinggi". Memperbaiki situasi atau kondisi tertentu dari kondisi yang sudah berjalan menuju peringkat yang berdaya saing itulah the real Muttaqin.

Dengan demikian, muttaqin merupakan idealisasi komunitas yang mawas diri, berdaya dan mampu berkompetensi dengan "yang lain". Dalam konteks makro, idealisasi itu dikonsepkan al-Qur' an sebagai "baldatun Thayyibatun wa Rabbun Ghafur". Konsep seperti ini mesti harus diwujudkan di tengah kehidupan kita melalui puasa. Berkaitan dengan hal ini Pudjo mengatakan:20 "Untuk itu, instropeksi harus terus dilakukan oleh semua elemen bangsa lebih-lebih para elit pemerintahan sebagai pengendali negara ini untuk terus berjalannya pada rel kehidupan yang berkarakteristik SDM muttaqin. Hanya dengan demikianlah, maka daya saing bangsa Indonesia akan lebih baik lagi dan bahkan manakala semua umat Islam di negeri ini mayoritas berpredikat muttaqin sangat mungkin posisi daya saing bangsa Indonesia berada pada peringkat urutan terhormat. Sehingga bukan tidak mungkin pula akan dapat diraih sebuah predikat paling bermartabat di mata Allah Swt. Yakni, negeri yang berpredikat baldatun thayybatun wa rabbun ghafur."

Jadi, idealisasi mengenai terwujudnya sebuah baldatun wa rabbun ghafur menjadi sangat penting berkaitan dengan makna puasa yang tujuan finalnya membentuk pribadi yang takwa. Muttaqin berarti cikal-bakal idealisasi negara tersebut, kaarena berangkat dari sebuah komunitaslah sebuah negara itu bisa dibangun.

Ulul Albab, Vol. 5 No. 2, 2004 


\section{Kesimpulan}

Dari uraian analisis diatas dapat diambil beberapa kesimpula sebagai berikut: Pertama, sejauh ini ibadah (puasa) telah mengalami pemaknaan yang beragam sesuai dengan prespektif dan demensi yang menjadi sudut pandang masing-masing cendikiawan. Kedua, perbedaan sudut pandang tersebut malahirkan beberapa corak pemikiran yang beragam. Yaitu, Formalistik, Transformatik, Realistik dan Idialistik, dimana masing-masing menampakkan kecenderungan ke arah upaya perubahan sosio-kultural.

\section{Endnotes}

1 Amin Abdullah, Studi Agama: Normativitas atau Historis?, (Pustaka Pelajar: Yogyakarta, 1996), hal. 23

2 Adi Sasono, dkk, Solusi Islam atas Problematika Ummat, (Gema Insani Press: Jakarta, 1998), hal. 202

3 Syafi'I Anwar, Pemikiran dan Aksi Islam di Indonesia, (Paramadina: Jakarta, 1995), hal. 11

4 Tatang M. Amirin, Menyusun Rencana Penelitian, (Jakarta, PT Raja Grafindo Persada, 1990),. 19

3 opcit Tatang M Amirin, , 132

- Syamsuddin M., Budayakan Iktikaf Pada Anak, Jawa Pos, Minggu 7 Nopember 2004

7 Nurhadiani, Puasa Versi Orang Pasaran, Jawa Pos, Selasa 9 November 2004

s Nurhadiani, Puasa Versi Orang Pasaran, Jawa Pos, Selasa 9 November 2004

9 Syamsul Arifi, Puasa, Volvo dan Kuda, Jowa Pos Selasa 2 November 2004

10 Syamsul Arifi, Puasa, Volvo dan Kuda, Jawa Pos Selasa 2 November 2004

1 M.A.Wicaksono, Gergaji Puasa, Jawa Pos Jum'at dan Sabtu, 5-6 November 2004

12 Muhaimin S., Shaim Sebagai Pemelihara al-Qur'an, Jawa Pos Minggu 31 Oktober 2004

13 Muhaimin S., Muhaimin S., Shaim Sebagai Pemelihara al-Qur'an, Jawa Pos Minggu 31 Oktober 2004

14 Muhaimin S., Shaim Sebagai Pemelihara al-Qur'an, Jawa Pos Minggu 31 Oktober 2004

is Muhaimin S., Niat Puasa dan Membangun Bangsa, Jawa Pos Sabtu 23 Oktober 2004 
16 Baharuddin, Ramadan dan Solidaritas Sosial, Jawa Pos Kamis 28 Oktober 2004

17 M.Zainuddin, Puasa: Jihad Pengari Kekerasan, Jawa Pos Kamis 6 November 2004

18 Imam Suprayogo, Puasa Pertegas Ukuran Keberhasilan Hidup, Jawa Pos Senin 18 Oktober 2004

19 Imam Suprayogo, Puasa Sebagai Proses Pendidikan, Jawa Pos Rabi 20 Oktober 2004

20 Pudjo Sugito, Ramadan dan Daya Saing Bangsa, Jawa Pos Rabu 3 Novemver 2004

\section{Bibliography}

Amin Abdullah, Studi Agama: Normativitas atau Historis?, (Pustaka Pelajar: Yogyakarta, 1996)

Adi Sasono, dkk, Solusi Islam atas Problematika Ummat, (Gema Insani Press: Jakarta, 1998)

Nurcholish Madjid, Tradisi Islam Peran dan Fungsinya dalam Pembangunan di Indonesia, (Paramadiana: Jakarta, 1997)

Sulastomo, Dkk, Kontekstualisasi Ajaran Islam, 70 tahun Prof. Dr. H. Munawir Sadzali, MA, (IPHI dan Yayasan Wakaf Paramadian: Jakarta, 1995)

Syafi'l Anwar, Pemikiran dan Aksi Islam di Indonesia, (Paramadina: Jakarta, 1995)

Syafii Maarif, "Islam, Politik dan Demokrasi di Indonesia," dalam Bosco Carvallo dan Dasrizal,

Taufiq Abudllah, "Islam, Sejarah dan Masyarakat" Pengantar untuk buku Taufiq Abdullah, ed., Sejarah dan Masyarakat; Lintasan Historis Islam di Indonesa, (Yayasan Obor: Jakarta, 1987)

Tatang M. Amirin, Menyusun Rencana Penelitian, (Jakarta, PT Raja Grafindo Persada, 1990)

Sutrisno Hadi, Metodologi Research I, (Yogyakarta,Andi Offset, 1994)

Suharsimi Arikunto, Prosesdur Penelitian Suatu Pendekatan Praktek, (Rineka Cipta: Jakarta, 1998),

Winarno Surakhmat, Pengantar Penelitian Ilmiah, Dasar Metode dan Tehnik, (Transito, Bandung, 1989)

Ulul Albab, Vol. 5 No. 2, 2004 